\title{
The Gas War, 1915-1918: If not a War Winner, Hardly a Failure
}

\author{
Edward M. Spiers
}

\begin{abstract}
Contemporary claims that gas warfare proved "a failure" during the First World War would have baffled wartime adversaries, who invested heavily in the research, development, and production of gas warfare. If poison gas, like other conventional weapons, never broke the stalemate of the trenches, it evolved into a weapon of harassment that compounded the effects of conventional weapons and degraded the effectiveness of enemy forces compelled to wear gas masks for protracted periods of time. The introduction of mustard gas in July 1917 greatly increased the number of gas casualties, and set the scene for a steady increase in the use of chemical weapons during the later stages of the war. Like the tank and aircraft, gas was not strategically decisive, but continuing investment in this form of warfare underscored its potential utility.
\end{abstract}

\section{Introduction}

The onset of chemical warfare in the First World War produced not only major scientific, industrial, and military challenges to the principal belligerents but also a legacy that has been fiercely debated. After the first major use of chlorine gas by German forces, when they dispersed chlorine from 5,730 cylinders along a 6-km front at Ypres on April 22, 1915 (McWilliams and Steel 1985, Chaps. 5 and 6), the gas war expanded prodigiously as the main belligerents introduced new and more potent gases and sought to deliver them more efficiently. Although the French and Germans had used irritant agents before April 22 (Trumpener 1975, 461-465), they later employed lethal agents such as chlorine, phosgene, and, above all, mustard gas as the primary instruments of gas warfare. Like the British, they enhanced their methods of gas protection, and dispersed gas by various means, including cylinders,

\footnotetext{
E.M. Spiers $(\square)$

University of Leeds, Leeds, UK

e-mail: e.m.spiers@leeds.ac.uk

(C) The Author(s) 2017

B. Friedrich et al. (eds.), One Hundred Years of Chemical Warfare: Research,

Deployment, Consequences, DOI 10.1007/978-3-319-51664-6_9
} 
mortars, projectors, and gas shells. The gas war, argued Major Victor Lefebure, became "one of continual attempts on both sides to achieve surprise and to counter it by some accurate forecast in protective methods. It is a struggle for the initiative" (Lefebure 1921, 109-110).

\section{Debate}

Assessing the significance of this struggle has produced a wide array of judgments. The allies, eying the response in neutral United States (Peterson 1939, 63; Read 1941, 195-199), denounced the first use of chlorine gas as "an atrocious method of warfare" which would "fill all races with a new horror of the German name" (The Times, April 29, 1915). Nevertheless, when they retaliated in kind, a reaction described "as just and necessary" (Brown 1968, 15), they did so without analyzing its effectiveness. Only at the end of the war were several British and American gas officers able to comment on the impact of chemical warfare. Major Samuel J. M. Auld, a former Chemical Advisor, British Third Army, argued that "the use of poisonous and irritating gases is as fundamental as the introduction of gunpowder, and probably even more so," and he extolled the effects of mustard gas during the last year of the war (Auld 1922, 58, 66). Amos A. Fries, an American engineer, who became Chief of the Chemical Warfare Service, described gas as "one of the most powerful means of offense with which the American troops had to contend" (Fries and West 1921, 386). Major-General Charles H. Foulkes, the former British Director of Gas Services (1917-18), insisted that gas had "changed the whole character of warfare." Gas, he observed, had seriously affected German morale during the last months of 1918, contributing "to the Allied victory": it was of "increasing" importance towards the end of the war, and "might have played a decisive part in 1919" (Foulkes 1936, 334, 336, 345). Brigadier-General Harold Hartley, a future Fellow of the Royal Society, claimed, too, that "gas is a very valuable weapon, as it supplements other weapons, offers great opportunities for surprise, and is a most effective means of achieving many tactical objects" (Hartley 1919-20, 504).

Revisionism followed the Second World War, a conflict in which poison gas was stockpiled massively but not used between the principal adversaries in Europe, in contrast to the Pacific Theater where the Imperial Japanese Army used chemical weapons from 1937 onwards in occupied China. In his final volume of the official history of the Great War, produced in 1947, Brigadier J. E. Edmonds contradicted much of his earlier writing (Edmonds et al. 1937, vol. 2, 163-164, 383, 390, 412) by observing that "[g]as achieved but local success; it made war uncomfortable, to no purpose. It was not used 1939-45" (Edmonds et al. 1947, vol. 5, 606 n.2). Julian Perry Robinson subsequently argued that the Germans had bungled the strategic potential of poison gas at Ypres, and that the introduction of respirators ensured that gas achieved only a "limited tactical success." The military establishments, he 
argued, became "decidedly lukewarm" towards this unpredictable weapon (Robinson 1971, 51-52, 59).

Several scholars have disputed the recollections of Foulkes, claiming that he exaggerated the effects of gas at Loos, overrated the value of cylinder-based gas-cloud attacks, and relied excessively upon the unreliable testimonies of prisoners of war (Haber 1986, 57, 279; Richter 1994, 3, 91-92; Griffith 1994, 116119). L. F. Haber even claimed that gas was a failure, despite some tactical successes as in precipitating the Italian defeat at Caporetto, October 24, 1917. He contended that gas failed at Second Ypres and Loos, and that it proved unpredictable as respirators blunted its effects: by complicating warfare, gas, unlike the tank, aircraft and the light machine gun, failed to change "the face of war in 1918" (Haber 1986, 264, 270, 278).

\section{Gas: Not a War Winner}

Poison gas was certainly not a war winner. Its use at the Second Battle of Ypres (April 22-May 25, 1915) followed the unexpected onset of trench deadlock and the failure of conventional weapons to break the stalemate. Professor Fritz Haber, who was then only an unofficial advisor to the German Ministry of War, had pressed the case for experimenting with chlorine gas. General Erich von Falkenhayn never appreciated the potential effects of releasing $149,000 \mathrm{~kg}$ of chlorine from 5,730 cylinders (McWilliams and Steel 1985, 41): he saw it as primarily a diversionary move "to cloak the transportation of the [German] troops to Galicia," and admitted that the "surprise effect was very great. Unfortunately we were not in a position to exploit it to the full. The necessary reserves were not ready. The success achieved, however, was considerable" (Falkenhayn 1919, 84-87).

This gas release was far from universally popular. While German infantrymen resented the labor of installing the cylinders in front-line trenches and the days spent waiting for favorable winds, Crown Prince Rupprecht of Bavaria worried that retaliation in kind by the Allies would benefit from the prevailing westerly winds (von Frauenholz 1929, vol. 1, 304-305), and Rudolph Binding wrote in his diary on April 24, 1915, "I am not pleased with the idea of poisoning men. Of course, the entire world will rage about it first and then imitate us" (Binding 1929, 64). This proved true, and Hartley claimed that the Germans had

made almost every possible mistake in their earliest gas attacks. They chose a gas against which protection could be obtained with comparative ease, they used it in small quantities on narrow fronts in discharges of long duration and low concentration, thus losing the effect in depth, and finally they failed to exploit the partial advantage they gained. Within three weeks we were protected (Hartley 1919-20, 493).

However correct in hindsight, this judgment overlooks "the fact" that the British "were aware" of German preparations for the gas attack for "several days previously" but assumed that "the enemy's attempt would certainly fail", and so "the 
terrible effect of the gas came to us as a great surprise" (TNA, WO 32/5483, "Account"). The gas release also caused mass panic among its victims, enabling the Germans to capture over 1,800 prisoners, "more than 51 guns, of which four were heavy, and about 70 machine guns" (Duguid 1938, vol. 2, 320) as well as ground they would hold for another two and a half years. Subsequent attacks were less productive; on April 24 the gas encountered a resolute defense led by Canadians, using improvised protection, to ensure "only a moderate dent in the line" (McWilliams and Steel 1985, 86, 155), and further gas attacks on May 1, 6, 10, and 24 failed to dislodge the Allied grip on the Ypres salient (Spiers 1986, 16-17).

The first designed British response was the Black Veil Respirator, a pad of cotton waste soaked in sodium thiosulphate, sodium carbonate, and glycerol held in place by a long piece of veiling. Issued in May 1915, it afforded only limited protection against chlorine, leaving Yorkshire soldiers to complain about the "rotten gas" that "nearly choked and blinded us" ("Letters" May 28 1915, 6). Much more effective was the Hypo Helmet, a bag with eyepieces and made of flannel, soaked in the impregnating solution, which was put over the head and tucked into the collar. The issue of 2.5 million copies during June 1915, prompted Driver E. Broadley to affirm: "our respirators kept us all right" during a subsequent gas attack ("Letters" June 25 1915, 6). The British later issued the $\mathrm{P}$ helmet, impregnated with phenate solution, in anticipation of the enemy using phosgene as they did on December 19, 1915. By adding hexamethylenetetramine, a Russian idea, the $\mathrm{PH}$ helmet gave enhanced protection against phosgene, but all helmets were unpleasant to wear. The British eventually devised a large box respirator (LBR) followed by the small box respirator (SBR), in which a flexible rubber tube connected the mask to a filter containing charcoal and sodium permanganate-lime granules. This afforded extra protection against prussic acid, and the SBR became the standard British respirator, issued to all troops by January $1917 .^{1}$

Yet Sir John French, then commander-in-chief of the British Expeditionary Force (BEF), never regarded defensive protection as an adequate response to chemical attacks. As he informed Lord Kitchener, the Secretary of State for War: "We are taking every precaution we can think of but the most effective would be to turn their own weapon against them \& stick at nothing" (TNA, Kitchener 1915). Many regimental officers and men agreed. The Germans were "dirty devils," wrote Lieutenant the Hon. William Fraser, "[b]ut we must play their own dirty game as far as the gas goes." Another Gordon Highlander, Lance-Corporal George Ramage, contended: "All war is foul. Why object to gas \& not to bullets" (NLS, Ramage 1915). Meanwhile, once Major-General Henry Rawlinson, commander of IV Corps, learned about the depth of the German underground bunkers, he maintained: "What we want is a favourable wind and plenty of good strong chlorine \& bromine gas which will sink right down into the deep trenches" (NAM, Rawlinson 1915).

\footnotetext{
${ }^{1}$ TNA, WO 32/5483, "Diary" and "Account"; WO 142/99, Fergusson 1915.

${ }^{2}$ Fraser, Lt. the Hon. William. 1915. Letter to his Father, May 3. In Fraser 1990, 52.
} 
The British cabinet required several meetings and "considerable discussion" before it approved retaliation in kind (TNA, CAB37/127 and 37/128, 1915). This followed on the first day of the battle of Loos, an offensive demanded by France. Sir Douglas Haig, commander of I Corps, who had reservations about the location and timing of the proposed battle, saw a successful trial discharge of gas at Helfaut on August 22 (IWM, Ashley August 22 1915). Henceforth he declared:

On the one hand, with gas, decisive results were to be expected. On the other hand, without gas, the fronts of the attacks must be restricted, with the result of concentrated hostile fire on the attacking troops, considerable loss, and small progress! In my opinion the attack ought not to be launched except with the aid of gas! (NLS, Haig 1915)

After successive postponements at the behest of General Joseph Joffre, the BEF launched its first gas assault on the morning of September 25, 1915, when Foulkes, who commanded the newly formed Special Companies of trained chemists, planned to release 150 tons of chlorine from 5,500 cylinders. He recorded in his diary: "Wind was almost calm-SSW-very unfavourable for a gas attack but the battle could not be postponed" (LHCMA, Foulkes 1915). Following the release of chlorine gas and smoke "alternately" (IWM, Ashley September 24 1915), the gas cloud facilitated the advance of the 15th and 47th Divisions on the right of the British attack and assisted the brief capture of the Hohenzollern Redoubt. Elsewhere it moved far too slowly, veering and hanging around the British trenches, with the effects on British forces compounded by leakages, faulty connections, and inadequate training. Even Foulkes, who always insisted that gas caused surprise at Loos, ${ }^{3}$ admitted that this attack had been one of "peculiar difficulty" and "extemporization and creation" (LHCMA, Foulkes 1933). Far from breaking through at Loos, the British suffered 59,000 casualties over three weeks, including 2,639 casualties and seven deaths from their own gas in the first three days (Palazzo 2000, 75-77).

\section{The Challenge of Chemical Warfare}

An inability to cause a breakthrough did not distinguish chemical weapons from any other weapon in 1915. Nevertheless, once used, gas could not be ignored and all the principal belligerents invested in its development. On the Western Front they undertook offensive and defensive research \& development, tested new gases and various delivery systems, produced the gases, munitions, and ancillary equipment for an expanding gas war, and formed special gas forces. Under Haber's leadership, the Kaiser Wilhelm Institute for Physical Chemistry and Electrochemistry became committed to the military in February 1916 and expanded steadily into nine departments in various locations around the suburbs of Berlin. By the end of the war it employed 150 academically trained staff, 1,300 non-commissioned officers,

\footnotetext{
${ }^{3}$ LHCMA, Foulkes 1915 and Foulkes n.d., 5: ch. 20; Foulkes 1936, ch. 5; Foulkes 1962, 179-80.
} 
soldiers, other workers, and additional support personnel. Meanwhile the centralization of French science enabled scientists and laboratories to forge close links between offensive and defensive research in Paris, with another department responsible for application and pilot-plant operation, and a third for purchases and dispatch. Conversely, the French reliance upon state-controlled and smaller independent gas enterprises, often located far from the front, never matched the economies of scale secured by the larger German industrial combines (Stoltzenberg 1993, 133-142; Coleman 2005, 25-26; Hartcup 1988, 105-106).

The British developed entirely separate groups working on offensive and defensive research but, in 1916, the War Office purchased 2,886 acres at Porton Down, where it established an experimental ground. The site expanded steadily over the remainder of the war until it occupied 6,196 acres and enabled Porton to examine 147 toxic substances and conduct field trials of new munitions. Porton also examined individual and collective protection when it acquired the Anti-Gas Department from the Royal Army Medical College in 1917. British industrial support, despite expanding to involve 70 factories by the end of the war, remained less productive than its German counterpart (Carter 1992, 7-25; Haber 1986, 172).

These organizational innovations, coupled with the formation of dedicated chemical corps, testified to the continuing interest in chemical warfare. Although disagreements recurred between scientists and senior military officers, improvisation flourished (Haber 1986, 174-175, 208, 273-274; Hartcup 1988, 106). ${ }^{4}$ Faulty cylinder connections, which caused gas leakage at Loos, and were described by R. C. Gale as "a ghastly failure" (IWM, Gale 1915, 70), were corrected with the use of rubber connections. Thereafter the British persisted with cylinders despite their weather dependence, the infantry's dislike of installing them at night in front-line trenches, fear of accidents, and the counter barrage from German gunners whenever the gas was released. ${ }^{5}$ As employing cylinders exploited the prevailing westerly winds, and offset the shortage of shells in Britain, the Special Brigade (as Foulkes's expanded force became known) launched 150 of the 220 gas-cloud attacks between April 1915 and November 1918, while the Germans launched 50 and the French 20 (Prentiss 1937, 52; Foulkes 1936, 184-186).

Quite apart from employing gas cylinders, the British introduced the 4-inch Stokes mortar at Loos. On account of its caliber and rate of fire (about twenty rounds a minute), this was an ideal gas weapon, as each round delivered 3 to $4 \mathrm{~kg}$ of agent at ranges up to $1,000 \mathrm{~m}$ (Prentiss 1937, 362-364). Foulkes praised the Stokes mortar as a versatile weapon that could be brought into action quickly and deliver concentrated amounts of gas over the target area. It could also project smoke barrages during an assault and bombard advanced enemy positions with thermit, bursting the bombs in the air and showering anyone below with globules of molten iron at "white heat" (LHCMA, Foulkes 1917).

\footnotetext{
${ }^{4}$ On disputes involving Foulkes, see IWM, Hodgkin August 21918 and Richter 1994, 183.

${ }^{5}$ TNA, WO 158/270, Barrow 1916; Winter 1979, 126.
} 
Another British invention was the projector, designed by Captain William $\mathrm{H}$. Livens, which was first used at the Somme before the discharge in a mass formation of 2,340 projectors at the opening of the battle of Arras (April 4, 1917). Easily and cheaply produced, the projector fired canisters holding about $15 \mathrm{~kg}$ of agent and was not weather dependent. Installed in the ground in batteries just behind the front lines at 45-degree angles, 4,000 projectors could be fired simultaneously by an electrical device. As the Livens projector set up sudden, very high concentrations of agent that neither mortars nor gas shells could emulate, large-scale usage ensued: 4,200 drums (and 3,100 Stokes mortar bombs) were discharged on the eve of the battle of Cambrai (November 1917) and 2,960 drums were fired into St. Quentin on March 19, $1918 .^{6}$ Less accurate than mortars or shells, projectors were limited in range (about 1,550 m), but the German 111th Division testified to their impact:

By this new procedure, the enemy has combined the advantages of gas cloud with those of gas shell, obtaining the density of the former with the surprise effect of the latter. Our losses have hitherto been heavy, because the enemy, in most cases, successfully took us unawares, and gas masks were put on too late (TNA, WO 158/294, July 8 1917).

Nevertheless, gas shells became the primary mode of gas delivery. Although Germany had pioneered the employment of lachrymatory Ni-Schrapnell and T-Stoff shells in the winter of 1914-15, and then K-Stoff shells in the Argonne sector on July 16, 1915, the French proved more innovative in fuse design. By using only a small bursting charge to open their phosgene shells, the French increased both the payload of the shells and the concentration of gas on target (February 1916). As the Germans responded with Green Cross shells, filled with the lethal agent, diphosgene (March 9, 1916), both adversaries exploited the advantages of artillery: accuracy, flexibility, and less dependency on the weather. ${ }^{7}$ Gunners ultimately delivered some $85 \%$ of the toxic gases during the First World War, and caused about $85 \%$ of the gas casualties (Prentiss 1937, 657, 660). Gas shells grew from a negligible proportion of artillery ammunition in 1915 to about $50 \%$ of the German, $35 \%$ of the French, $25 \%$ of the British, and $20 \%$ of the American ammunition expenditure by the Armistice. Had the war continued into 1919, all the belligerents planned to employ even more chemical shells. ${ }^{8}$

Gas shells complemented other forms of shelling, as the gases released were multi-purpose area weapons. In preparing for the battle of the Somme, the BEF borrowed 60,000 phosgene shells from France for use in "surprise" salvoes "on front-line trenches, when parapets are manned, and also for counter-battery work" (TNA, WO 158/234). Colonel Georg Bruchmüller refined German artillery tactics on the Eastern Front to neutralize hostile batteries and fire short but highly intensive bombardments at "gas squares." Thereafter his batteries attacked infantry and artillery strong points with as much as 50 or $80 \%$ gas shells (TNA, WO I33/1072, Hartley n.d., 8-9). Gas shells were also used to intercept enemies moving at night or

\footnotetext{
${ }^{6}$ REM, R15, Crowden Report, 1917; History of the Corps 1952, 5: 522.

${ }^{7}$ TNA, WO 188/213, Hartley n.d.; Lepick 1998, 182, 184-185.

${ }^{8}$ Prentiss 1937, 657-658, 660, 683-684; TNA, WO 188/213, Hartley n.d.
} 
in advance of night-time raids: as Captain A.E. Hodgkin observed, it was easier to take a German prisoner "when he has got his gas mask on" (IWM, Hodgkin May 23 1918). Latterly, when on the defensive, Germans exploited the persistent effects of mustard gas by saturating areas with Yellow Cross liquid and compelling attacking parties to avoid the contaminated terrain (TNA, WO 158/128, Foulkes 1918).

Similar developments occurred on the Eastern Front. Having experimented unsuccessfully in the cold weather at Bolimov with 18,000 T-stoff shells (January 31, 1915), the Germans mounted large-scale poison-gas attacks with cylinders, beginning at Rawka (May 31, 1915). Exploiting the Russian lack of preparedness and protection, they delivered at least ten cylinder attacks over the next eighteen months before introducing more accurate chemical shelling (Main 2015, 116-20, 136). Although estimates of Russian gas casualties are disputed (ibid., 130-131; Prentiss 1937, 653; Krause and Mallory 1992, 16-17), the Russian chemist Professor Vladimir N. Ipatieff, who chaired the Commission for the Preparation of Explosives and later the Chemical Committee of the Chief Artillery Administration, claimed that in the first attack "seven to eight thousand men were poisoned in one night, the majority of whom died" (Eudin et al. 1946, 221). Heavy gas casualties persisted, reflecting recurrent lapses in anti-gas discipline, transport, and distribution problems, and delays in producing effective gas masks through a Tsarist bureaucracy, riven with corruption and incompetence (ibid., 218-226, 230-231).

Over a year elapsed before Russia, hampered by its industrial shortcomings, could retaliate in kind, and, in the second attack, all the casualties were Russian (Main 2015, 126; Krause and Mallory 1992, 26-27). Despite both sides mounting gas operations with cylinders, they used shells predominantly in 1917, where Bruchmüller earned his nickname "Durchbruchmüller" ("breakthrough Müller") for artillery assaults, using "gas squares" at the Stochod, East Galicia, and Riga in April, July, and September respectively. In establishing a bridgehead across the Stochod, German gas shells incapacitated the 27th Artillery Brigade and accounted for the capture of two Tsarist divisions. German artillery also employed intense gas barrages in the capture of Seret in East Galicia and in the forcing of the Dvina River in the Riga operation. ${ }^{9}$

What sustained the development of the gas war was the search for more effective chemical warfare agents. The criteria of battlefield effectiveness meant that only several dozen of the thousands of toxic substances examined were employed militarily. This process was still underway in the last few weeks of the war, when the Germans began looking for an agent with more persistence than mustard gas (Robinson 1971, 38-51; Coleman 2005, 26). These substances had to be produced in significant quantities from available materials, thereby confirming the huge advantage that the large German dyestuffs industry had over its rivals. Chemical agents had to be stable in storage, non-corrosive in munitions, relatively safe to handle and transport, and deliverable from a practical military device in sufficient concentration to produce the desired effect on target. Understanding all these

\footnotetext{
${ }^{9}$ TNA, WO 42/195, Hicks 1917, 204-205; TNA, WO 33/1072, Hartley n. d., 9.
} 
properties took time, fuelling friction between scientists and the military, and between the military and those in charge of wartime supply.

Of the harassing agents used, lachrymators (tear-gases) were employed throughout the war. In 1917, the Germans introduced a new class of solid arsenical sternutators (causing sneezing). Dubbed Blue Cross agents, diphenylchloroarsine (DA) and diphenylcyanoarsine (DC) proved highly irritating but good mask discipline could blunt their effects. The British hoped that adamsite (DM), developed during 1918, would prove a mask-breaking agent in 1919, if used extensively (Robinson 1971, 38-51; Coleman 2005, 26). The Germans led the way in the use of chlorine and phosgene (lethal lung agents), followed by the Allies, with the British employing 50/50\% combinations in their White Star gas clouds. The French hoped that the highly toxic blood gases, hydrogen cyanide (prussic acid) and cyanogen chloride, would become effective war gases, but these highly volatile substances had to be mixed with stabilizers, diluents and smoke-markers, and so lethal dosages proved difficult to deliver. The Germans introduced mustard gas (bis (2-chloroethyl) sulfide) at Third Ypres on July 12, 1917 and, by only using it when they had a vast stock available, delivered 2,500 tons of mustard gas in the first ten days from over one million Yellow Cross shells. ${ }^{10}$

\section{Effectiveness of the Gas War}

The so-called "king of the war gases" transformed the gas war. Highly effective in low concentrations, mustard gas had a slight odor and delayed action, which, coupled with its persistence and capacity to burn and blister through clothing, defied the defensive precautions of the day. Wearing a respirator could thwart its fatal effects, and spreading decontaminants-chloride of lime on guns and bleaching powder on the ground-helped, but mustard gas produced a massive number of casualties. In the first three weeks of Yellow-Cross shelling, the British incurred more casualties (14,276), and almost as many deaths (nearly 500), as they had suffered from all previous gas engagements. From July 12, 1917 to November 23,1918 , British casualty clearing stations admitted 160,970 gas casualties, 1,859 of whom died. $77 \%$ of these were victims of mustard gas. ${ }^{11}$

All of the casualties had to be removed for treatment to the rear; the more lightly blistered with swollen eyelids, like Captain Richard Foot, might recover in a week (IWM, Foot n.d., 98); others like T. H. Holmes, gassed on August 22, 1918, found their fighting career over (IWM, Holmes n.d.). As Tim Cook asserts, the best weapons were those that "remove fighting men and leave fear and unrest among the survivors" (Cook 1999, 215): in other words, mustard gas had a psychological effect upon everyone in a gassed area. Its slight odor was difficult to detect amongst

\footnotetext{
${ }^{10}$ Robinson 1971, 46; TNA, WO 188/213, Hartley n.d.

${ }^{11}$ Macpherson et al. 1923, 2: 294 and 304-308; TNA, WO 142/99, 1917.
} 
the odors of the battlefield and its delayed action caught soldiers unawares, especially those newly deployed at the front. Mustard gas penetrated former places of safety - shell craters and trenches-, demoralizing the tired and exhausted. In rear areas, too, doctors, nurses, and orderlies had to learn how to treat their patients without suffering from cross-contamination. ${ }^{12}$

Having seen 1,400 men gassed in the Villers Bretonneux area, Rawlinson wrote to Winston Churchill, then Minister of Munitions, on April 22, 1918:

Can you give me any idea when we may expect to have available shells filled with mustard
gas? I ask because we have had very severe casualties lately from this form of projectile
[...] The men naturally feel that the enemy has a distinct advantage over us in possessing
mustard gas and the contention of our chemists that our own lethal shells are still more
effective, a contention with which I do not agree, is no satisfactory answer. We feel that we
are at a disadvantage in this respect and morale suffers as a consequence (NAM, Rawlinson
1918).

Chemical weapons had already become established as a weapon of harassment. In preparations for the battle of the Somme, British army commanders dispersed gas and smoke amidst the preliminary artillery bombardments at "selected places along the whole British front," compelling the enemy "to wear his gas helmets," induce "fatigue," and cause casualties (TNA, WO 256/10, Haig 1916). The ensuing 110 cylinder discharges, mainly dispersing White Star gas clouds at night, harassed the enemy and caused operational degradation. Foulkes later insisted that a cylinder gas cloud was "far more searching in its effects than the cloud produced by projectiles," since it swept over a much more extensive area, penetrating "every nook and cranny," and tested the enemy's defenses more extensively than any other means of discharge (LHCMA, Foulkes, 1917).

Foulkes sought to maximize these benefits by introducing the retired cylinder or beam attack in 1918. Less hazardous to the infantry, who were withdrawn from the front lines when the attacks occurred, the operations involved thousands of cylinders loaded onto flatcars, brought up by rail (or in one case by lorries and horse-drawn wagons) to rear-area positions, and then releasing the gas simultaneously by electrical detonators. Despite losing cylinders in transport accidents, and suffering delays due to lack of wind, the Special Brigade launched ten beam attacks, releasing gas from 27,000 cylinders and achieving greater concentrations of gas than in previous cylinder operations. ${ }^{13}$

Most gas commanders, though, preferred the flexibility of gas shells, projector drums, and mortar bombs. On all sides gunners experimented with the different types of shell and variations in the volume and rate of fire to achieve surprise, inflict casualties, and neutralize enemy batteries or at least reduce the rates of artillery fire. When faced with British gas shells at the battle of Arras, a German commander emphasized the "complete protection" of the German respirators, but acknowledged

\footnotetext{
${ }^{12}$ Cook 1999, 149-154, 216-17; Heller 1984, 65, 80; Winter 1979, 122-123.

${ }^{13}$ TNA, SUPP 10/292, Foulkes 1918; IWM, Hodgkin July 4-23 1918; LHCMA, Bunker 1965; Foulkes 1936, 291. For a critique of these operations, see Richter 1994, 200-230.
} 
that the "fighting resistance of the men suffered considerably from wearing the mask for many hours." Even worse, horses suffered severely from gas and so the ammunition supply faltered and "the timely withdrawal of batteries could not be affected" (TNA, WO 158/294, von Below 1917).

Various forms of harassment occurred. Once able to fire projectors and 4-inch Stokes mortars in combination, the British bombarded enemy front-line strong points, combining gas with smoke and thermit. Using eleven different fillings in the Stokes mortar bombs and projector drums, the Special Brigade attacked at "all hours of the day and night, and in all wind velocities," even dead calm (TNA, SUPP10/292, Foulkes 1918, 3). They occasionally repeated attacks from the same front after a few hours' interval or disguised attacks by feints with smoke. All this ingenuity reflected the effectiveness of the German respirator once it received a 3-layer drum in June 1916 and further fillings in April 1918. As the Allies were unlikely to penetrate this respirator unless it was damaged or defective, ${ }^{14}$ they tried to catch the enemy unawares, distract him, or degrade his fighting efficiency. Even a diversionary bombardment, as took place south-east of Lens in July 1917, involved the delivery of 3,564 drums of gas and 909 mortar bombs across a $3.7 \mathrm{~km}$ front over five nights (REM, Crowden, August 3 1917).

During March and April 1918, including Operation Michael (March 21-April 5) the Germans discharged a massive volume of gas. As early as March 9, their " 150,000 to 200,000 rounds of Yellow Cross shell [...] caused heavy casualties" and, on the morning of March 21, "some millions of rounds of gas shell" targeted forward posts, trenches, strong points, batteries to a depth of $4.8 \mathrm{~km}$, and villages to a depth of $12.9 \mathrm{~km}$. Although the Blue Cross and Green Cross shell combination failed, as the British SBR blocked the penetration of Blue Cross agents, respirators had "to be worn for many hours, thus adding greatly to the strain and fatigue, and hampering movement and communication" (Hartley 1919-20, 499). Intensive gas shell bombardments continued into April 1918, with estimates of 30,000 to 40,000 rounds poured into Armentières on the night of April 7-8, reportedly leaving the gutters running with mustard gas (ibid.; Edmonds et al. 1918, vol. 2, 163).

The SBR minimized fatalities but protection came at a price in fighting efficiency. As Captain Arthur A. Hanbury Sparrow (Royal Berkshires) observed:

We gaze at one another like goggle-eyed, imbecile frogs. The mask makes you only half a man. You can't think. The air you breathe has been filtered of all save a few chemical substances. A man doesn't live on what passes through the filter-he merely exists. He gets the mentality of a wide-awake vegetable (Hanbury-Sparrow 1932, 309).

German soldiers subsequently bore the brunt of such harassment when the Allies moved onto the offensive in August 1918. The Canadians employed gas shells, up to $20 \%$, in preliminary assaults upon German batteries, command posts, assembly trenches, observation points, and lines of communication (Cook 1999, 189-90). The American Expeditionary Force (AEF) emulated French artillery tactics, both rapid intense gas bombardments at short range to catch the enemy by surprise, and

\footnotetext{
${ }^{14}$ TNA, SUPP 10/292, Foulkes 1918, 2; History of the Corps 1952, 5: 523.
} 
longer, slower barrages to induce fatigue and lower the enemy's physical resistance and morale. They discharged gas in support of infantry attacks, involving $25 \%$ of the ordnance delivered. They also employed Stokes mortars in groups, firing phosgene (as well as smoke and thermit) to attack machine-gun nests, weaken resistance, and inhibit counter-attacks (Heller 1984, 86, 88). As soon as the French acquired mustard-gas shells in March, and the British in September, they incorporated them into their fire-plans: over four days from September 26, 1918 onward, the British Fourth Army fired 750,000 shells at the Hindenburg Line, including some 30,000 mustard-gas shells (Lloyd 2014, 181).

Neither at the time nor subsequently has it been possible to evaluate the exact impact of these chemical attacks. Foulkes lacked evidence about the effects of over half the attacks mounted by the Special Brigade, and the remaining evidence from British observation, the testimony of prisoners and deserters, and German letters, diaries and official documents found on the battlefield related largely to the "losses of small units" (TNA, SUPP 10/292, Foulkes 1918, 3). Both Haber and Richter rightly questioned whether much of this evidence withstood scrutiny, both the value of wartime testimony by prisoners of war and deserters, and post-war evidence from incomplete medical records, including the suspicions of malingering among a disproportionate number of the American gas casualties. ${ }^{15}$ Yet Richter, unlike Haber, accepts that gas was perceived as a valuable means of harassment (Richter 1994, 224). The steadily increasing use of poison gas by all belligerents on the Western Front, coupled with plans to use it on an even greater scale in 1919, had the war continued, underscored this perception (Palazzo 1999, 39-50; Prentiss 1937, 684).

Finally, any assessment of poison gas during the Great War has to accept that gas was only used because conventional weapons had failed to break the deadlock of the trenches. Thereafter the belligerents relied primarily upon conventional ordnance, namely 2 million tons of high explosives and 50,000 million rounds of small arms ammunition (Prentiss 1937, 656, 662). Nor did the other novel weapons - the tank and airplane - "change the face of war" as Haber alleged (Haber 1986, 270). The Germans employed only nine tanks in their spring offensive and the British used tanks in masses on only two days during the entire war. Neither Cambrai on November 20, 1917 nor Amiens on August 8, 1918 proved decisive because the British lost the vast majority of their machines (of the 414 sent into battle on August 8, only 145 were available one day later and, by August 12, a mere six machines were able to continue). As John Terraine argued: "The German empire was not going to be overthrown by six tanks, any more than by Trenchard's ten bomber squadrons at Nancy" (Terraine 1978, 116). Although the British and French employed aircraft in unprecedented numbers in 1918, dropping 543 tons of bombs on German targets from June 6 until November 11, 1918, these aircraft had only a supportive role. Limited by meteorological conditions during

\footnotetext{
${ }^{15}$ Haber 1986, 246-248; Richter 1994, 92; US Department of War, Surgeon General's Office, 1926, XIV: 65.
} 
the autumn, these aerial operations were not decisive in 1918 (Edmonds et al. 1947, vol. 5, 577; Terraine 1982, 274-275, 304-306).

In short, chemical weapons were only one of several novel weapons introduced during the Great War. None of these weapons proved war winners in and of themselves, and none of them broke the deadlock of the trenches. All the major belligerents experimented with new gases and means of delivery; they ensured thereby that chemical warfare evolved in scope and method and grew steadily in tonnage, albeit within a largely supportive role. For the British army, the Special Brigade discharged 87,968 cylinders and fired 196,940 projector drums as well as 177,408 Stokes mortar bombs, delivering some 5,700 tons of gas (TNA, SUPP 10/292, Foulkes 1918, 3). By 1919, the British mounted aerial gas attacks against the Bolsheviks, hardly evidence of any failure shrouding the sense of inquiry and experimentation with poison gas (TNA, WO 106/1148, Ironside 1919).

Anti-gas defenses may have been a priority throughout the war, but if the respirators saved lives, they did so at the price of operational degradation and proffered scant protection against the burning and blistering properties of mustard gas. The desperate desire of the Allies to retaliate in kind as soon as they acquired mustard gas in 1918 demonstrated their concerns about the psychological effects and the perceived operational utility of poison gas. As Hanbury-Sparrow observed:

It wasn't so much the harm it did to the body, which was always much over-estimated in the popular imagination, as the harm it did to the mind [...] this harmless-looking almost invisible stuff would lie for days on end lurking in low places waiting for the unwary. It was the Devil's breath (Hanbury-Sparrow 1932, 309-310).

This was hardly a weapon that failed.

\section{References}

Auld, Major Samuel. 1922. Chemical warfare. Royal Engineers Journal 35: 57-71.

Binding, Rudolph. 1929. A fatalist at war. Trans. Ian F.D. Morrow. London: G. Allen \& Unwin.

Brown, Frederick J. 1968. Chemical warfare. A study in restraints. Princeton, NJ: Princeton University Press.

Carter, Gradon B. 1992. Porton Down: 75 Years of chemical and biological research. London: HMSO.

Coleman, Kim. 2005. A history of chemical warfare. Basingstoke: Palgrave Macmillan.

Cook. Tim. 1999. No place to run: The Canadian Corps and gas warfare in the First World War. Vancouver and Toronto: University of British Columbia.

Duguid, Colonel A. Fortescue. 1938. Official history of the Canadian Forces in the Great War 1914-1919. 2 vols. Ottawa: J. O. Patenaude.

Edmonds, Brigadier-General Sir, E. James, et al. 1937. Military operations: France and Belgium, 1918, vol. 2. London: HMSO.

Edmonds, Brigadier-General Sir, E. James, et al. 1947. Military operations: France and Belgium, 1918, vol. 5. London: HMSO.

Eudin, Xenin, Helen D. Fisher, and Harold H. Fisher (eds.). 1946. The life of a chemist. Memoirs of Vladimir N. Ipatieff. California: Stanford University Press. 
Falkenhayn, General Erich von. 1919. General Headquarters $1914-1916$ and its critical decisions. London: Hutchinson.

Foulkes, Major-General Charles H. 1936. 'GAS!' The story of the special brigade. Edinburgh and London: Blackwood.

Foulkes, Major-General Charles H. 1962. Chemical Warfare now, and in 1915. Royal Engineers Journal 76: 177-84.

Fraser, David (ed.). 1990. In good company: The First World War letters and diaries of the Hon. William Fraser, Gordon Highlanders. London: Michael Russell.

Fries, Amos A., and Clarence J. West. 1921. Chemical warfare. New York: McGraw-Hill Book Co.

Griffith, Paddy. 1994. Battle tactics of the Western Front: The British Army's Art of Attack, 191618. New Haven: Yale University Press.

Haber, Ludwig F. 1986. Poisonous Cloud: Chemical warfare in the First World War. Oxford: Clarendon Press.

Hanbury-Sparrow, Lt.-Col. Arthur A. 1932. The land-locked lake: Impressions of active service in the European War. London: Arthur Baker.

Hartcup, Guy. 1988. The war of scientific invention: Scientific developments, 1914-18. London: Brassey's Defence Publishers.

Hartley, Brig.-Gen. Harold. 1919-20. A general comparison of British and German methods of gas warfare. Royal Artillery Journal 46: 492-509.

Heller, Major Charles E. 1984. Chemical warfare in World War I: The American experience, 1917-18. Leavenworth Papers No. 10. Fort Leavenworth.

The history of the corps of royal engineers. 1952. vol. 5. Chatham: The Institution of Royal Engineers.

Imperial War Museum (IWM). 85/22/1. Lt. Charles Allen Ashley. 1915. Diary, August 22 and September 24.

IWM. 86/57/1. Brigadier-General Foot. n.d. Once a Gunner.

IWM. 66/163/1. R. C. Gale. 1915. Diary, September 28.

IWM. 06/30/1. T. H. Holmes, n.d. Memoirs.

IWM, P. 399. Captain Adrian E. Hodgkin. 1918. Diary, May 23, July 4-23, and August 2.

Krause, Joachim, and Charles K. Mallory. 1992. Chemical weapons in Soviet Military doctrine: Military and historical experience, 1915-1991. Boulder: Westview Press.

Lefebure, Victor. 1921. The riddle of the Rhine: Chemical strategy in peace and war. London: Collins.

Lepick, Olivier. 1998. La grande guerre chimique: 1914-1918. Paris: Presses Universitaires de France.

Letters From The Front. 1915a. Bridlington Free Press, May 28.

Letters From The Front. 1915b. Bridlington Free Press, June 25.

Liddell Hart Centre for Military Archives (LHCMA). King's College London. 2/16. Foulkes Mss. 1915. Diary, 25 September.

LHCMA. 6/13. Foulkes. 1917. Notes on the offensive use of gas and methods of gas discharge. Lecture delivered to commanders and staff officers of the Second Army at Helfaut, April 28.

LHCMA. 6/61. Foulkes. n.d. Draft of his chapter for the History of the Royal Engineers 5: Chap. 20.

LHCMA. 6/78. Lt.-Col. S.W. Bunker. 1965. 50th Anniversary Re-union Dinner, 25 September.

LHCMA. G/119. Foulkes. 1933. At a Gas Services Reunion Dinner, February 4.

Macpherson, Walter Grant, et al. 1923. History of the Great War: Medical services. Diseases of War. London: HMSO.

McWilliams, James, and R. James Steel. 1985. Gas! The Battle for Ypres, 1915. St. Catharine's, ON: Vanwell.

Lloyd, Nick. 2014. Hundred Days: The campaign that ended World War I. New York: Basic Books.

Main, Steven J. 2015. Gas on the Eastern front during the First World War (1915-1917). Journal of Slavic Military Studies 28: 99-132. 
National Army Museum (NAM). Rawlinson Mss. Add Mss. 1952-01-33-18. Rawlinson. 1915. Letter to Maj.-Gen. W.P. Braithwaite, June 25.

NAM. Rawlinson Mss. Add. No. 1952-01-33-21, Rawlinson. 1918. Letter to W.S. Churchill, April 22.

National Library of Scotland (NLS). Acc. 3155. Haig Mss. 1915. Diary, September 16.

NLS. Ms 945. Ramage. 1915. Diary, May 15.

New Technical Weapons. 1915. The Times, April 29.

Palazzo, Albert. 1999. Plan 1919-The other one. Journal of the Society for Army Historical Research 77: 39-50.

Palazzo, Albert. 2000. Seeking victory on The Western front: The British Army and Chemical Warfare in World War I. Lincoln and London: University of Nebraska Press.

Peterson, Horace C. 1939. Propaganda for war: The campaign against American Neutrality, 1914-1917. Norman, OK: University of Oklahoma Press.

Prentiss, Augustin M. 1937. Chemicals in war: A Treatise on chemical warfare. New York, NY: McGraw-Hill.

Read, James, M. 1941. Atrocity Propaganda 1914-1919. New Haven, CT: Yale University Press.

Richter, Donald. 1994. Chemical soldiers: British gas warfare in World War I. Barnsley: Leo Cooper.

Robinson, Julian Perry. 1971. The rise of CB weapons. In The problem of chemical and biological warfare, ed. Stockholm International Peace Research Institute, vol. 1. Stockholm: Almqvist \& Wiksell.

Royal Engineers Museum (REM), R15. Special Brigade re. Gas in World War 1 1915-18.

Crowden. 1917. Report on Operations of the Special Companies, R.E. attached to Canadian Corps, July 15 th to August 15 th.

REM. R15. Crowden. 1917. Operation Order No. 4/C, August 3.

Spiers, Edward M. 1986. Chemical Warfare. London: MacMillan Press.

Stoltzenberg, Dietrich. 1993. Fritz Haber: Chemist, Nobel Laureate, German, Jew. Philadelphia: Chemical Heritage Press.

Terraine, John. 1978. To win a war. London: Sidgwick \& Jackson.

Terraine, John. 1982. White Heat: The New Warfare 1914-18. London: Book Club Associates.

The National Archives (TNA). Cabinet Mss. CAB 37/127. 1915. Henry H. Asquith to King George V, 27 April and CAB 37/128. 1915. Asquith to King George V, May 5.

TNA. PRO 30/57. Kitchener Mss. French. 1915. Sir John French to Lord Kitchener, April 27.

TNA. SUPP 10/292. Brigadier-General C. H. Foulkes. 1918. Report on the Activity of the Special Brigade During the War, December 19.

TNA. War Office. WO 32/5483. n.d. An Account of German Cloud Gas Attacks on British Front in France.

TNA. WO 32/5483. n.d. Diary of Development of British Respirator.

TNA. WO 33/1072. Brigadier-General H. Hartley. n.d. Report on German Chemical Warfare Organisation and Policy, 1914-1918.

TNA. WO 42/195. Captain W. L. Hicks. 1917. Gas Services Reports from Russian Front.

TNA. WO 106/1148. Maj.-Gen. Edmund Ironside. 1919. Letter to Gen. Rawlinson, September 16.

TNA. WO I33/1072. Brigadier-General Harold Hartley. n.d. Report on German Chemical Warfare Organization and Policy, 1914-1918.

TNA. WO 142/99. Lt.-Gen. Charles Fergusson. 1915. Gas Attack on VI Corps, December 22.

TNA. WO 142/99. 1917. Report on the Gas Shell Bombardment at Nieuport on Night of 21/22nd July.

TNA. WO 158/128. Brigadier-General C. H. Foulkes. 1918. Summary of Hostile Gas Activity, October 18

TNA. WO 158/234. Lt.-Gen. Lawrence Kiggell. 1916. Memorandum, June 19 and Maj.-Gen. Archibald A. Montgomery. 1916. Report of the Army Commanders remarks at the conference held at Fourth Army headquarters, 22 June 1916, June 24.

TNA. WO 158/270. Gen. George de S. Barrow. 1916. Report, First Army No. 852(G), August 18. 
TNA. WO 158/294. 1917. Effect of British Gas Projectors, containing extract from an order of the 111th Division, July 8.

TNA. WO 158/294. Gen. Fritz von Below. 1917. Experiences Derived From the Arras Battle, April 11 and Hartley. n.d. British and German Methods of Gas Warfare.

TNA. WO 188/213. Brigadier-General H. Hartley. n.d. Chemical Warfare.

TNA. WO 256/10. Haig Diary. 1916. Army Commanders Conference at HQ Third Army, May 27. Trumpener, Ulrich. 1975. The road to Ypres: The beginnings of gas warfare in World War I. Journal of Modern History 47: 460-480.

United States Department of War, Surgeon General's Office, 1926, Medical department of the U.S. Army in World War. Medical aspects of gas warfare. XIV. Washington, D.C.: War Department.

von Frauenholz, Eugen (ed.). 1929. Kronprinz Rupprecht von Bayern, Mein Kriegstagebuch, vol. 1. Munich: Deutscher National Verlag.

Winter, Denis. 1979. Death's Men: Soldiers of the Great War. London: Penguin.

Open Access This chapter is licensed under the terms of the Creative Commons Attribution-NonCommercial 2.5 International License (http://creativecommons.org/licenses/by-nc/ $2.5 /$ ), which permits any noncommercial use, sharing, adaptation, distribution and reproduction in any medium or format, as long as you give appropriate credit to the original author(s) and the source, provide a link to the Creative Commons license and indicate if changes were made.

The images or other third party material in this chapter are included in the chapter's Creative Commons license, unless indicated otherwise in a credit line to the material. If material is not included in the chapter's Creative Commons license and your intended use is not permitted by statutory regulation or exceeds the permitted use, you will need to obtain permission directly from the copyright holder.

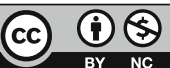

